\title{
Improving Efficiency of Teaching the Tatar Language to a Foreign Audience
}

\author{
Yusupov Ruzal Abdullazyanovich ${ }^{1}$, Aydarova Svetlana Hanipovna ${ }^{1}$, Sagdieva Ramilya Kamilovna ${ }^{1} \&$ \\ Harisova Gulnaz Faritovna ${ }^{1}$ \\ ${ }^{1}$ Kazan Federal University, Kazan, Russia \\ Correspondence: Yusupov Ruzal Abdullazyanovich, Kazan Federal University, Kremlevskaya Street 18, Kazan \\ 420111, Russia.
}

Received: November 14, 2014

Accepted: January 5, 2015 Online Published: April 28, 2015

doi:10.5539/ies.v8n5p158

URL: http://dx.doi.org/10.5539/ies.v8n5p158

\begin{abstract}
In the article we consider the state of teaching the Tatar language in Russian schools as one of the two official languages in the Republic of Tatarstan, we reveal reasons for teaching inefficiency of this language in schools, and give recommendations aimed at improving the effectiveness of teaching of the Tatar language, improving teaching methods, as well as developing textbooks on the Tatar language for those studying it as a foreign language.
\end{abstract}

Keywords: learning, teaching, native language, Russian language, school, textbooks, methodology, Russian-language schools, communicative approach, language mistakes, features of the native language

\section{Introduction}

The need to pay more attention to the problems of the Tatar, Russian and other languages in the multinational republic of Tatarstan is due to the concern with development of the spiritual life and culture of Tatars, Russians and other peoples living in the republic, as well as providing friendship and mutual understanding between them.

Being aware of the crucial importance of this thesis, at the time the parliament of Tatarstan adopted the Law on Languages of the Peoples of the Republic of Tatarstan, and the state program for implementation of this Act. These laws envisage preservation, study and development of the Tatar, Russian and other languages of the Republic, as well as promotion of the conservation and study of the native language of many Tatars settled in many regions of Russia and beyond the country. The Constitution of Tatarstan declares the Tatar and the Russian languages as state languages of the Republic of Tatarstan (Constitution of 2012).

The Constitution of Tatarstan declares the Tatar and the Russian languages as state languages of the Republic of Tatarstan. Success in implementing key provisions of these laws is largely dependent on the state of learning the Tatar language and a language level of the republic population, especially of a younger generation. And therefore, issues of organization of teaching the Tatar language are constantly in the spotlight of corresponding authorities and the head of the republic.

The Ministry of Education and Science of the Republic of Tatarstan did extensive work in pursuance of the law on languages, in particular provisions concerning teaching the Tatar and Russian languages in equal volume. Due to the perceived need to urgently cover a lot of thousands of Russian-speaking students learning Tatar for a significant amount of time, the ministry had to organize an unprecedented teaching of Tatar to a huge number of students, additionally engaging hundreds of thousands of teachers, developing new textbooks, programmes, teaching materials and finding ways to provide many thousands of students with new textbooks on the Tatar language and literature.

In order to improve the learning process of the Tatar language of Russian-speaking students and improve its efficiency, the Ministry of Education and Science of Tatarstan took a number of necessary measures aimed at the successful solution of the global task of teaching the Tatar language.

In particular, alternative and original programmes on the Tatar language and literature were created (Safiullina, Ahmadullina, \& Yahina). Different groups of authors developed three series of textbooks on the Tatar language for Russian students: a completed series for 1-11 classes by the authors-Fathullova \& Safiullina; a series for 1-11 classes by the co-authors-Haydarova \& Malafeeva, and the series of Litvinov \& Nigmatullina (Safiullina \& 
Fathullova, 2004; Haidarova \& Rangulova, 2000).

In the framework of increasing the prestige of the state bilingualism, enhancing language training and updating education content, the objectives of designing effective teaching methods of the Tatar language as a state language are achieved. Russian-speaking groups of secondary schools of Tatarstan were offered a model of intensive study of the Tatar language and foreign languages based on the technology of concentrated learning (Kharisov \& Kharisova, 2014). The teaching materials on the Tatar language for 5-7 grades "Tatarcha da yahshy bel" were successfully tested in 108 secondary schools, these materials are based on the technology of concentrated learning of the Tatar and foreign languages. The performance of teachers and students was actively tracked, results on testing the teaching materials were obtained, teachers and parents were repeatedly surveyed on the topic. However, currently the situation with the learning the Tatar language in Russian-speaking audience remains difficult.

\section{Methods}

This study was carried out according to the following methods:

- We studied the literature on teaching the Tatar language in Russian-speaking audience, as well as on teaching foreign languages to students;

- We examined textbooks on the Tatar language for Russian-speaking students;

- We analyzed the lessons of the Tatar language in Russian schools that had attended; have studied the experience of students learning a foreign language;

- We took into account results of interviews with teachers of the Tatar language and literature, as well as with parents of students enrolled in Russian schools of the city of Kazan.

\section{Results}

Acquaintance with letters of parents, teachers and scientists sent to the President of the Russian Federation, as well as to the President of Tatarstan, the analysis of the state of teaching the Tatar language in Russian-language schools, interviews with students, their parents and teachers and, most importantly, the low level of the Tatar language of school graduates give grounds to assert that the results of teaching Tatar in Russian-speaking audience, in general, are not comforting, though, of course, in some schools certain teachers are quite successful. Today the situation is such that most of Russian schools graduates, who have studied the Tatar language for 11 years in a quite extensive manner, do not master the Tatar language even in an average degree, and are not able to correctly and expressively communicate in this language. The only exceptions are those graduates of Russian schools, whose families deliberately teach their native Tatar language to their children.

The reasons for this situation are as follows:

Firstly, a level of professionalism of many teachers of the Tatar language cannot meet the high requirements due to the fact that in the early 1990s with the adoption of the Law on languages a large amount of non-specialists joined their ranks-not only non-scholars but even non-pedagogues, a certain percentage of which continues to work in this field. Even for teachers who have received a diploma of higher pedagogical education in "Philology", successful teaching the Tatar language in Russian-language schools is problematic. Now, in fact, we do not specifically prepare teachers of the Tatar language and literature for work in Russian schools: such teachers mainly work that are trained to work in Tatar schools. From the above fact, it must be concluded that there is a need to specifically prepare teachers of the Tatar language and literature for the Russian-speaking audience and moreover at the highest level.

To teach the Tatar language and literature to Russian-speaking students is the most complicated task that requires many qualities from the teacher: knowledge of age physiology, pedagogy, psychology; excellent knowledge of the Russian language; skills to arouse students' interest in the Tatar language and bring up a sense of friendship, tolerance, etc. (Aydarova \& Salimzyanova, 2012)

The second major reason for the problem is wrong teaching methods. Teaching Tatar to Russian-speaking pupils should be conducted using the method of teaching the Tatar language as a foreign language. The current practice of teaching Tatar to Russian-speaking students cannot have a positive result, especially due to the fact that it is focused on providing students with lexical and grammatical material outside the context of its operation, outside coherent speech. In teaching Tatar as a foreign language, the main principle is the communicative one: as the main problem in language teaching is to teach the student to communicate, to know how to speak that language (Asadullin, 2000). According to Professor Shakirova L., communicative orientation of language teaching puts forward a number of linguistic principles, based on data of the linguistic science: distinction of language and 
speech, language and speech systemic organization, approach to a language as to a special sign system and speech activity, attention to semantic content of the language. Mastering the system of linguistic resources is a necessary condition, material for acquiring skills and abilities to speak and write (Shakirov, 2002). Note that the best results in teaching Tatar to Russian-speaking pupils are achieved by those teachers who are working with the method of teaching foreign languages. Such teachers are Litvinov, Nigmatullina, Haydarova, \& Malafeeva (Naberezhnye Chelny), Zamalieva (school №13 in Kazan) and others.

The third reason for the problem is the fact that existing programmes do not meet modern requirements. A serious drawback of the existing programme is its complexity. The programme content of the Tatar language for Russian students little differs from the programmes of the Tatar language for native speakers. Topics such as multi-component complex sentences (kyp tezməle, kyp iyarchenle katlauly kushma жөmlələr) (material of the 9th grade), etc. does not contribute to the development of speech, but also completely eliminates positive motivation of educational success: aversion to the subject and often refusal to study appear. Consequently, development of qualitatively new alternative programmes is one of the urgent tasks.

The next problem in achieving the quality of teaching the Tatar language in Russian schools is introduction of separate language and literature teaching for Russian-speaking students with different programmes and textbooks. According to any methodology, learning a foreign language speech activity should not be divided into the language and the literature as different subjects, it needs to be a united, interrelated process on the basis of one programme, one textbook. In case of separate education we lose the basic mechanism of the educational process of foreign language speech activity-cyclicality.

Nevertheless, in conditions of bilingual Tatarstan, getting Russian-speaking students acquainted with the Tatar literature and art is necessary in order to ensure a high level of general culture, mutual friendship, and tolerance of the republic peoples. At the same time it should be noted that most of these so-called Russian-speaking pupils are children of the Tatars (Kharisov et al., 2014). However, it would be appropriate to introduce the Tatar literature as a separate subject into the educational process in high school, and to use texts-extracts from artistic works-for the junior grades as teaching material in solving communicative problems. Note that texts of literary works should be selected strictly according to the level of understanding and perception of children. Meanwhile, the current practice of teaching the Tatar literature in Russian schools requires serious adjustments, as in some cases it does not reach its target due to the fact that some of the works, we can even say some textbooks are simply incomprehensible for students.

It is known that providing students with solid knowledge depends, primarily, on the clearly laid out, didactically methodically grounded textbook.

The author of the textbook should possess a significant set of skills not included in the profession of teachers, methods specialists and linguists. Elaborating a textbook is a special, the most complicated and delicate profession. An author of a textbook is a designer who designs all the activities of a teacher and students (very daunting task!). Designer, as the high-end specialist, works in his/her working time. As for authors of textbooks, many authors are forced to create their books outside of working hours, after their main job, at the expense of his/her rest. Of course, this affects quality of textbooks.

Methodical construction of existing textbooks on the Tatar language for Russian learners is motivated by the desire to keep up with the declarative slogan "equal proficiency in both official languages". Despite the fact that the teaching process of Russian-speaking pupils learning the Tatar language has been carried out for nearly twenty years, in reality, many graduates cannot communicate freely even on elementary social and everyday topics, not to mention the same proficiency of two state languages.

The main feature of the learning process of any language is its communicative orientation. On the lessons of the Tatar language such skills are formed which are primarily aimed at the practical use of the language as a means of communication. These skills are developed, as it is known, along with the mastery of the Tatar language means-language material. Implementation of educational and instructional purposes occurs when achieving practical tasks. Monitoring the development of students' speech shows that the desire of students to have informative speech and access to useful and interesting information from other people's speech comes into conflict with their limited language vocabulary. Difficulties in learning the target language speech are related to the fact that fluency is impossible without making certain automatism. Such activities are implemented faster and easier while conducting various didactic language games. At the initial stage of learning a foreign speech role-playing games play a prominent role and not by chance. During the game it is easier to digest the studied material; games help children to overcome shyness, to have faith in their own strength. During the game all the abilities sometimes appear. And finally, younger students love to play (Aidarova, 2001). 
Main reasons for rejection of the textbooks on the Tatar language in Russian-language schools by pupils and teachers are great generalization of topic, uncertainty of basic lexical and grammatical rules of each topic, a large lexical scope that has not been learned in previous grades and which is difficult for children of this age to understand. Sometimes texts are saturated with up to $50-60 \%$ of complex expressions, phraseology, Arab-Persian loanwords which are incomprehensible to students. Moreover, there is no connection between lesson speech materials linguistically: each lesson of these textbooks is accompanied by a new text. Meanwhile, according to scientific research, a student forgets $80 \%$ of the information that he has received at a lesson on the same day; $20 \%$ of information is stored a bit longer, depending on the degree of relevance to learners. Consequently, a question arises: how should a pupil learn a new material daily, the material which contains at least 3-4 grammatical phenomena, 20-30 new words? Moreover, there is no connection between exercises of one lesson lexically and linguistically. Often each exercise includes a new volume of lexical, grammatical material, which is completely unrelated to each other, and is not connected with the linguistic material from the previous and subsequent lessons, although, according to psychology, each newly introduced word must be repeated at least 8-12 times during one lesson.

Sociological studies conducted in the city of Kazan show the effectiveness of teaching materials created by Litvinov, Nigmatullina, \& Haydarova. Books of these authors are evaluated primarily as "good" and "excellent."

These studies refer to the lack of good textbooks $(73 \%)$ and programmes $(51 \%)$ as the main difficulties in quality of the educational process.

Developing textbooks on the Tatar language and literature for Russian-speaking pupils with pronounced communicative orientation allows meeting the challenges of forming active verbal and cogitative activities of students and their ability to actively communicate, as it is required from Russian-speaking pupils in the existing language environment of the Republic of Tatarstan.

A theoretical analysis of the existing concepts of teaching a second language gives us an opportunity to highlight a communicative learning technology, which is designed to ensure the effective organization of verbal communication in the classroom and, therefore, the optimal proficiency.

Reliance on the phenomenon of the native language when learning a foreign language is one of the important factors in the methodology of language teaching, and it certainly should be present in the process of teaching Tatar to Russian-speaking pupils (Kharisov \& Kharisova, 2004; Shakirov, 2002; Asadullin \& Yusupov 1995; Popper, 1963). Meanwhile, we cannot state yet that in the Tatar language teaching the corresponding students' knowledge of the Russian language is fully used (Fatkhullova, Zamaletdinov, \& Yusupova, 2013). In any case, there is reason to declare this, referring to the overwhelming majority of the numerous books on the Tatar language (except textbooks of Litvinov, Nigmatullina, and Haydarova).

The teacher's knowledge of the features of the Tatar language in relation to the Russian language is a must, as it helps him/her to correctly identify at what linguistic facts most attention should paid to, when it is necessary to resort to a comparison of patterns of these languages, in what sequence to place material for learning, what system of exercises should be provided (Programme, 1995).

First of all, it is necessary to consider facts of language, similar in Tatar and Russian, among which full compliance is detected (Shakurov, 2010). In this case, at lessons of the Tatar language it is possible to refer to facts of the Russian language (to name a similar term, with the help of translation from Russian to Tatar to show similarities or differences). Thus, thanks to presence of similar semantics of parts of speech in the Tatar and Russian languages it is not required to re-formulate definitions, which are known to students from the course of the Russian language. For example, when studying nouns it is advisable to uncover a meaning of concepts of the subject with the help of words, names of things, persons, materials, living things, events, phenomena (including natural phenomena), names of abstract qualities, properties, actions that are common phenomena in both languages.

Using students' corresponding knowledge of the Russian language makes it possible to avoid duplication of identical concepts, allows paying maximum attention to development of Tatar language skills.

Linguistic facts, denoted by the same term, and which are equivalent in their functions in Tatar and Russian, but have their own specific characteristics need special attention (e.g., the category of case, number, animate-inanimate nouns, the category of mood and tense of the verb and et al.). Identifying general and specific phenomena of two languages by comparing allows eliminating interferential errors of students in the use of certain words and forms of the Tatar language (Yusupov, 2009; Kirillova, 2014; Aydarova, 2013).

A quantitative analysis of the written works has shown that for elementary school pupils the greatest difficulty in 
speech and writing is the use of case forms of nouns, the possessive case $\left(3^{\text {rd }}\right.$ person singular: Apamiseme Rita instead of Apamnyщ̧iseme Rita (The sisters name is Rista) or Dniem iceme Natalia Vasilyevna instead of Әniemneџ ісете Natalia Vasilyevna (my mother's name is Natalia Vasilyevna), the accusative case (Min gailom yaratam instead of Min gailamne yaratam (I love my family)), the case of place and time: Oti militsiya eshli instead of Dti militsiyada eshli (Dad works in the police), etc., the use of category of person of the verb in the present tense: Min teshlarne chistarta instead of Min teshlarne chistartam (I brush my teeth) or Min ikenche syinyfta ukyi instead of Min ikenche syinyfta ukyim (I'm in the second grade); the use of personal pronouns ( $3^{\text {rd }}$ person singular and plural: Ul pensionerlar instead of Alar pensionerlar (They are retired)), the possessive case with the additive case: Anyp 52 yash instead of Aỵa 52 yash (he (she) is 52), Minem tugyzyash instead of Mił̧a tugyz yash (I am 9 years old); the use of verbs of the middle voice: Annary kYlmək, kofta, tun kienam instead of Annary kylmak, kofta, tun khiyam (Then I put on a dress, jacket, coat); verbs of the indefinite form: Min yaratam ukyim instead of Min ukyrga yaratam (I love to study); the use of certain lexical items: Min ayga baram instead of Min oyga kaitam (I'm returning home), etc. Russian-speaking pupils have difficulties with the order of words in a sentence. For example, in the story "Minem gaila" ("My Family") there is such sentence as "Bezneł gaila Chistai uramynda" instead of "Bezney gailə Chistai uramynda yashi" (Our family lives on the Chistopolkaya street).

Experience demonstrates that, firstly, the study of all sections of the Tatar language is effective only when it is accompanied by systematic work using a differentiated approach that takes into account the capabilities of each student and his/her knowledge and skills. Secondly, principles of the differentiated approach should be applied in all forms of learning activities (lessons, homework, academic competitions and other extracurricular classes) (Aydarova, 2001).

Analysis of the conducted tests and observations has allowed us to document a higher level of skills of students to correctly and accurately reproduce the oral and written language when using the differentiated approach; apply knowledge in any new situation creatively and independently; use previously obtained knowledge for a long time and use it to build correct Tatar speech.

\section{Discussion}

Being aware of the fact that many of the textbooks on the Tatar language for Russian-speaking pupils that are widely used today in schools do not meet modern requirements and do not allow reaching the proper level of knowledge of the Tatar language by students, the Ministry of Education and Science of the Republic should take drastic measures to create new textbooks, which would have amounted to a solid base and the correct orientation of radical improvement of students' quality of knowledge and skills of the Tatar language and literature. In our opinion it is necessary to take the following steps to perform this task:

- To conduct a rigorous objective examination of today's textbooks, engaging the most competent professionals;

- To establish a creative team of textbooks authors from the best teachers, highly qualified linguists and literary critics;

- To explore possibilities for quite complete financial incentives for authors to create better textbooks;

- To establish a system for providing textbook authors with sabbaticals.

- A textbook on the Tatar language for foreign audience should:

1) Ensure formation of self-esteem and self-analysis skills of students;

2) Contribute to:

- development of communicative competence (speech and language competences);

- development of motivation to learn; intellectual and creative activity;

- formation of patriotism;

- tolerant attitude towards different religious groups, inter-ethnic and inter-religious dialogue;

3) Take into account peculiarities of a certain age group.

- Teaching material in the textbook should be structured, systematic and consistent.

- Methodological tools of the textbook should:

-ensure mastering methods of selection, analysis and synthesis of information on a specific topic, testing and self-testing of mastered material, skills of independent learning activities, 
use of acquired knowledge in practice;

-develop skills of semantic reading;

-provide an opportunity for students' group work.

It is necessary to mention one more problem associated with ensuring students' proper level of the Tatar language-quality control system for mastered knowledge and skills of Russian-speaking students (Shakurova \& Mirzagitov, 2014).

According to a number of competent professionals engaged in teaching Tatar to Russian-speaking pupils and in developing experimental teaching methods, the current system of control of a level of the Tatar language of Russian-speaking pupils is in need of revision and serious improvement. According to them, there are the following problems in this system:

- The main object of control remains uncertain;

- Ways of checking students' oral skills are not developed;

- Oral language skills are considered as the joint use of language material;

- Estimating the level of language is oriented on absolute correctness of speech;

- Assessment is associated with language mistakes and not implementation of a communicative act;

- There are too rigid criteria of evaluation, etc.

In popular practice of teaching Tatar to Russian-speaking pupils, teachers' control is mostly aimed at checking errors and defects in grammar, pronunciation and spelling.

Such one-sided approach to control is due to the fact that the task of teaching at schools for many years was understood primarily as mastering the grammar material, and teaching to use the material in speech activity was underestimated. The main objects of knowledge control for pupils must be, above all, oral skills (Kharisov et al., 2009).

In order to substantially improve the efficiency of learning the Tatar language in Russian-language schools it is necessary:

- To teach the Tatar language to pupils of Russian schools, mostly with the communicative principle, using the differentiated approach in teaching;

- To develop the Tatar language textbooks for Russian-speaking pupils, also relying on the communicative method of language teaching;

- To put into practice teaching the Tatar literature in Russian-language schools as a special discipline in high school; to use individual works of Tatar writers at lessons of the Tatar language, mainly as illustrative material.

\section{Conclusion}

Thus, the conducted research of teaching the Tatar language in Russian-language schools shows that the current level of knowledge of students and graduates of the Tatar language does not meet the high demands of humanitarian training of young people who are able to continue their education and successfully work in a multilingual environment of the republic.

As follows from the article, low effectiveness of teaching the Tatar language to students in schools with the Russian language of teaching is mainly due to work of teachers of the Tatar language and literature with the methodology developed for Tatar schools, which doesn't allow successful learning of the Tatar language in Russian-language schools.

The article provides recommendations for improving the effectiveness of teaching the Tatar language, as well as for developing textbooks on methods of the Tatar language teaching as a foreign language.

\section{References}

Aidarova, S. (2001). Didactic conditions of exercises differentiation in the process of teaching the Tatar language to Russian-speaking pupils (Auto abstract submitted for obtaining the candidate of pedagogical sciences). Kazan: Tatar State Humanitarian Institute.

Aidarova, S., \& Salimzyanova, F. (2012). Formation of tolerance at the lessons of the Tatar language. Russia in XXI century: results, challenges, perspectives. Proceedings of the III International scientific-practical conference. Moscow: "Institute of Economics and Business"; Tyumen: LLC "East Consulting". 
Asadullin, A. (2000). Tatar language. For teachers working with Russian-speaking students. Grade 7. Kazan: Centre of History and Theory of National Education, Institute of History of the Academy of Sciences of Tatarstan.

Asadullin, A., \& Yusupov, R. (1995). Programme for practical lessons of the Tatar language in Russian-speaking audience (compilers). Kazan: Magarif.

Asadullin, A., \& Yusupov, R. (1995). Tatar language in Russian-speaking audience. Kazan: Magarif.

Constitution of the Republic of Tatarstan. (2012). Kazan.

Fatkhullova, K., Zamaletdinov, R., \& Yusupova, A. (2013). Information-Communicative Devices for Tatar Language Teaching. World Applied Sciences Journal, 1(26), 103-107.

Harisov, F., Harisova, Ch., Sagdieva, R., \& Garipova, V. (2014). Tatar language: A textbook for 4th grade of secondary schools with Russian language of teaching (for Tatar children). Kazan: "Magarif-Vakyt".

Khaidarova, R., \& Rangulova, A. (2000). Tatar language. Textbook for Russian-speaking students. Kazan: Magarif.

Kharisov, F., \& Kharisova, Ch. (2004). Tatar language. The textbook for the 5th grade of a secondary school with Russian as the language of teaching. Kazan: Magarif.

Kharisov, F., \& Kharisova, Ch. (2014). Bilingualism and multilingualism in a globalized society. Life Science Journal, 11(11s), 439-443. Retrieved November 7, 2014, from http:/www.lifesciencesite.com

Kharisov, F., Kharisova, G., \& Aidarova, S. (2009). Tatar language in a foreign audience. Textbook for high schools. Kazan: Magarif.

Kirillova, Z. (2014). The process of implementation of the Tatar language as a state language in 1920-1930. Life Science Journal, 11(12), 291-294. Retrieved November 7, 2014, from http://www.lifesciencesite.com55

Popper, N. (1963). Tatar Manual: Indiana University Publications. Uralic and Altaik Series, 25. The Hague.

Safiullina, F., \& Fathullova, K. (2004). Tatar language. Textbook for Russian-speaking students. Kazan: Magarif.

Shakirova, L. (2002). Teaching Russian in Tatar schools: Theory and practice. Kazan: Magarif.

Shakurova, M. (2010). Formation and development of the Tatar language teaching methods in a foreign audience. Scientific Tatarstan, 3, 207-214.

Shakurova, M., \& Mirzagitov, R. (2014). Linguistic analysis of Tatar language textbooks for non-Russian students. Life Science Journal, 10(11), 674-677.

Yusupov, R. (2009). General and specific in languages with different structures. Kazan: TSHPU.

\section{Copyrights}

Copyright for this article is retained by the author(s), with first publication rights granted to the journal.

This is an open-access article distributed under the terms and conditions of the Creative Commons Attribution license (http://creativecommons.org/licenses/by/3.0/). 